\title{
Review and Research on Non-Market Strategy of Enterprises Based on Chinese Transition Period
}

\author{
Yixuan Liu \\ School of Business Administration, South China University of Technology, Guangzhou, China \\ Email: 201620124231@mail.scut.edu.cn
}

How to cite this paper: Liu, Y.X. (2017) Review and Research on Non-Market Strategy of Enterprises Based on Chinese Transition Period. American Journal of Industrial and Business Management, 7, 643-651. https://doi.org/10.4236/ajibm.2017.75048

Received: May 3, 2017

Accepted: May 22, 2017

Published: May 25, 2017

Copyright $\odot 2017$ by author and Scientific Research Publishing Inc. This work is licensed under the Creative Commons Attribution International License (CC BY 4.0).

http://creativecommons.org/licenses/by/4.0/

\begin{abstract}
With the bloom of the study of non-market strategy, the field is very complex; the theories are different from each other and there are great differences between Chinese and foreign enterprises. In view of these problems, we combed the relevant literature of non-market strategy of EBSCO and CNKI database from 2006 to 2016, and tried to find out the theoretical perspective of the existing non-market strategy research. Based on this research, we examine the applicability of European and American enterprises' practical experiences to Chinese enterprises and provide practical suggestions and guidance for non-market activities of Chinese enterprises during the specific period of Chinese transition.
\end{abstract}

\section{Keywords}

Non-Market Strategy, Rational Perspective, Political Perspective, Ethical Perspective

\section{Introduction}

Since Baron put forward "non-market" strategy, it has been a research hotspot from the past 20 years. And Baron thinks the concept of non-market strategy is a kind of specific strategy which focuses on the relationship of enterprises with government, public and stakeholders [1]. Non-market strategy can improve the legitimacy of the existence of the enterprise. Especially under the background of Chinese economic transformation, it can pave the way for market strategy, or integrate with market strategy effectively to improve enterprise performance. The Baron's non-market environment is divided into four parts: issues, mechanism, interests and information. Non-market environment is formed by interac- 
tion between enterprises and enterprises, enterprises and society of the social, political and legal arrangements; it is composed of public, shareholders, government, media and public institutions that have the majority rule, legal procedures, extensive autonomy, characteristic of collective action and the public [2]. However, because of the diversity of differences between the disciplines and research perspective, the research in the field of non-market strategy is a little messy, unsystematic and needs to be further clarified. This paper also gives reference and suggestions for enterprises under specific institutional environment during the period of Chinese transition.

\section{Literature Review}

We use "non-market strategy", "corporate political strategy", "enterprise and government" and "enterprise and society" as key words, finding 81 related English and Chinese papers from EBSCO and CNKI database between 2006 to 2016. Among them, there are 69 papers in journals and 12 dissertations; 33 theoretical research papers and 48 empirical research papers. Because there are many different research perspectives and schools on non-market strategy, we sort out and classify the existing literatures as follows.

\subsection{Concept of Non-Market Strategy}

Scholars' definition of non-market strategy can be basically divided into two aspects: one is the definition of a non-market strategy as a behavior model of enterprise. The other is the definition of a non-market strategy as a cognitive model. Baron defines non-market strategy as a consistent action taken by an enterprise during non-market environment to increase the overall value [3]. Lin Shu and $\mathrm{Gu}$ Biao believe that non-market strategy refers to the enterprise's interactive behaviors during non-market environment (from government, public, media, social institutions and other stakeholders), rather than only the narrow sense as "relations between enterprises and public policy [4]."

\subsection{Classification of Non-Market Strategy}

As the theoretical analysis tools are numerous and jumbled, there are three main perspectives in the field of non-market strategy types, the first is based on the model of non-market strategy: buffer strategy and bridging strategy. The second is based on the type of non-market matters during non-market environment, there are three strategic types currently: political strategy, social responsibility strategy and public and media strategy. According to the social exchange theory, the third can be divided into transaction oriented non-market strategy and relationship oriented non-market strategy [5] [6].

Western scholars tend to use the classification of non-market strategy model, domestic scholars are more inclined to take the classification of non-market events, but these two classifications are not contradictory [7]. When enterprises are in the implementation of non-market strategy, it must be based on the impact of the existence of non-market matters to take appropriate strategic ap- 
proach. With the background of Chinese transition economy, the non-market environment characteristics are dynamic, complex and unforeseen, so it is more inclined to deal with the classification of non-market events.

\subsection{Influencing Factors of Non-Market Strategy}

Due to the use of complex analysis tools, thus the conclusion of research on the factors of non-market strategy shows the trend of diversification. We set the theoretical basis of literature analysis as the starting point, the theory of representative scholars and research results are summarized in Table 1.

Table 1. Comparison of different perspectives.

\begin{tabular}{|c|c|c|c|}
\hline $\begin{array}{l}\text { Theoretical } \\
\text { basis }\end{array}$ & $\begin{array}{l}\text { Influential factors and } \\
\text { representative scholars }\end{array}$ & $\begin{array}{c}\text { Research } \\
\text { contribution }\end{array}$ & $\begin{array}{l}\text { Research } \\
\text { limitations }\end{array}$ \\
\hline $\begin{array}{l}\text { Resource-based } \\
\text { theory }\end{array}$ & $\begin{array}{l}\text { Enterprise scale (Rehbein \& Cramer, 2002; Hillam, 2003; } \\
\text { Meznar \& Night, 1995); Diversification of enterprises } \\
\text { (Hillman \& Wan, 2005; Hillman \& Hitt, 1999); } \\
\text { Department of public affairs } \\
\text { (Lenways \& Rehbein, 1991); Political preferences of executives } \\
\text { (Blumentritt, 2003); Enterprise growth (Ye Guangyu, 2011); } \\
\text { Bargaining power (GOMES-CASSERES, 1990) }\end{array}$ & $\begin{array}{l}\text { Extend asset } \\
\text { attributes to } \\
\text { intangible resources } \\
\text { and capabilities }\end{array}$ & $\begin{array}{l}\text { Too much emphasis } \\
\text { on internal resources, } \\
\text { while ignoring the } \\
\text { external resources }\end{array}$ \\
\hline $\begin{array}{l}\text { Institutional-based } \\
\text { theory }\end{array}$ & $\begin{array}{l}\text { Institutional environment at the national level } \\
\text { (Hillman, 2003); Industry management system } \\
\text { (Sohuler, 2002); Enterprise level (Tian Zhilong, 2005) }\end{array}$ & $\begin{array}{l}\text { From the perspective } \\
\text { of the internal } \\
\text { resources and } \\
\text { capabilities of } \\
\text { the enterprise }\end{array}$ & $\begin{array}{l}\text { A comparative study } \\
\text { on the lack of developed } \\
\text { economy, new economy } \\
\text { and transitional economy }\end{array}$ \\
\hline Stakeholder Theory & $\begin{array}{c}\text { Employees, government, shareholders, } \\
\text { community, public (Agle, Mitchell \& Wood, 2000) }\end{array}$ & $\begin{array}{l}\text { Taking into account } \\
\text { the interests of all } \\
\text { stakeholders, rather } \\
\text { than just pay attention } \\
\text { to the interests of } \\
\text { enterprises }\end{array}$ & $\begin{array}{l}\text { In the case of resource } \\
\text { constraints, how to } \\
\text { balance the } \\
\text { contradictions and } \\
\text { conflicts between } \\
\text { stakeholders }\end{array}$ \\
\hline $\begin{array}{l}\text { Corporate social } \\
\text { responsibility theory }\end{array}$ & $\begin{array}{l}\text { Responsibility for employees and shareholders } \\
\text { (Baron \& Diermeie, 2007); Public welfare activities and } \\
\text { charitable acts, the protection of the rights and interests } \\
\text { of consumers, the protection of employees' rights and interests, } \\
\text { the protection of ecological environment (Xie Peihong, 2010) }\end{array}$ & $\begin{array}{l}\text { From the perspective } \\
\text { of economic } \\
\text { research to the study } \\
\text { of enterprise ethics }\end{array}$ & $\begin{array}{l}\text { The lack of research } \\
\text { on the motivational } \\
\text { factors of corporate } \\
\text { social responsibility }\end{array}$ \\
\hline $\begin{array}{l}\text { Transaction } \\
\text { cost theory }\end{array}$ & $\begin{array}{l}\text { Collective action or act alone } \\
\text { (Hillman, 1999); Asset specificity or public } \\
\text { goods attributes (Grier, 1994) }\end{array}$ & $\begin{array}{l}\text { Using economic } \\
\text { indicators to } \\
\text { measure the cost of } \\
\text { non-market strategy }\end{array}$ & $\begin{array}{l}\text { Concerned about the } \\
\text { short-term interests of } \\
\text { enterprises, ignoring the } \\
\text { long-term interests } \\
\text { of enterprises }\end{array}$ \\
\hline Social capital theory & $\begin{array}{c}\text { Executive social network } \\
\text { (Blumentritt, 2003; Shao Jianbing, 2010) }\end{array}$ & $\begin{array}{l}\text { Research on the } \\
\text { mechanism of } \\
\text { influencing factors }\end{array}$ & $\begin{array}{l}\text { Ignore the nature of } \\
\quad \text { ownership } \\
\text { (Private enterprises, and } \\
\text { state-owned enterprises) }\end{array}$ \\
\hline $\begin{array}{c}\text { Resource } \\
\text { dependence theory }\end{array}$ & $\begin{array}{l}\text { Reduce dependence on external } \\
\text { (Frooman, 2001; Pandi, 2011) }\end{array}$ & $\begin{array}{l}\text { The effect of } \\
\text { resource dependence } \\
\text { on the choice of } \\
\text { non-market strategy }\end{array}$ & $\begin{array}{l}\text { Selection, control } \\
\text { and manipulation of the } \\
\text { external environment }\end{array}$ \\
\hline
\end{tabular}

Source: according to relevant literature. 


\section{Theoretical Perspectives of Non-Market Strategy}

In view of the above literature researches and thinkings, we found that the existing corporate non-market strategy research can be attributed to three major perspectives of rationale, politics, and ethics. Different perspectives come from different disciplines, so the study has focused on different scopes. The rational perspective emphasizes the development of non-market strategy and its impact on economic performance, the political perspective emphasizes the balance of power between the enterprise and its stakeholders, and the ethical perspective emphasizes the moral connotation of enterprise behavior. According to this classification, the following parts will be combined with the existing literature, sum up the theoretical basis of each perspective, basic assumptions, research topics and corresponding empirical conclusions one by one.

\subsection{Rational Perspective of Non-Market Strategy}

From the literatures, the rational perspective occupies the dominant position from the existing non-market strategy. At rational perspective, the purpose of the existence of enterprises is to pursue the maximization of economic benefits; the enterprises use the development of strategies to match the environment and try to create the best performance for themselves. Based on this assumption, Schuler pointed out that non-market strategy is the use of competition during non-market environment. The use of political strategies to influence the formulation of public policy, is driven by the government and regulatory authorities to create a more favorable competitive environment for enterprises to win the competitive advantage. According to the logic of rational perspective, the purpose of non-market strategy is to win the political advantage, and the political advantage is to serve the market competition [8] [9] [10] [11]. Therefore, non-market strategy is the bedding or auxiliary of the market strategy. Enterprise managers use non-market strategy to change the rules of market competition, and try to consolidate market strategy.

Above all, we can see that the rational perspective emphasizes the utility of non-market strategy which government is a competitive tool for enterprises; however non-market strategy is the investment of the public goods, the ultimate goal is to use the power of the government to win private interests. From the scope of the study, the rational perspective focuses on "the relationship between the enterprise and public policy" [12]. For example, Getz used principal-agent theory to describe the relationship between government and enterprises. She regards the enterprise as one of the principals of public policy, and the government is the agent of many interest groups in the field of public policy, including the enterprises.

To sum up the empirical results, we can clearly see that the rational perspective emphasizes the matching between specific non-market strategies and specific enterprises, and this kind of matching is ultimately beneficial to maximize corporate profits. So the fundamental standpoint of rational perspective is to understand the non-market behavior of enterprises from the input-output logic 
[13]. Non-market strategy is a kind of investment, and political advantage and economic performance are the expected output; the goal of the enterprise is how to optimize the input-output function. In a word, the rational perspective mainly focuses on the optimal solution of non-market field, but it seldom deals with the political, humanistic and symbolic nature of an organization.

\subsection{Political Perspective of Non-Market Strategy}

Different from the rational perspective focuses on specific enterprises, the political perspective of non-market strategy research is devoted to exploring the power relationship between the enterprises and its stakeholders. From the political perspective, the enterprise is an open system which is embedded in social, political and cultural environment-government, community, employees, consumers, suppliers and other groups are actors or stakeholders of the enterprise. Enterprises rely on their stakeholders to protect their own survival, and stakeholders use the enterprise to achieve their rights and interests. There are not only cooperation and complementarity of resources between enterprises and their stakeholders, but also conflicts of interest and competition. The enterprise is always in the complex relationship's network which is constituted by its stakeholders. Based on this view, political perspective holds the opinion that non-market strategy is a way for enterprises to coordinate conflicts of interest. The key to the implementation of non-market strategy is to find the balance of power in the relationship network and try to alleviate the conflicts of interest among different groups and realize the resource sharing in the network [14] [15].

In addition to the theme of "how companies should manage their stakeholders", another key point is how stakeholders influence corporate's decisions. Around this issue, Frooman conducted an investigation for 140 chief executives and it is found that the extent which influences stakeholders' decision of the enterprises depends largely on the power contrast between them [16]. If the stakeholders have a strong dependence on the resources of the enterprise, the enterprise is more powerful than the stakeholders. In this case, stakeholders tend to take the initiative to provide adequate resources for the enterprise, in order to influence or interfere in the decision-making process.

According to the above empirical literature, we can clearly see that it is different from the rational perspective which just emphasizes the economic performance. Political perspective pays more attention at series of variables like "conflict of interest", "stakeholder commitment", "stakeholder satisfaction" and "power relations". From the political perspective, the essence of non-market strategy is the interaction between enterprises and interest groups; the goal is not to maximize the economic benefits, but to "mitigate conflicts of interest", "improve stakeholder commitment and satisfaction" and "balance the power". In this sense, the political perspective is to find the equilibrium solution, but not the optimal solution. Compared with the rational perspective, the political perspective is more comprehensive to take into account the human nature and political nature of the organization. 


\subsection{Ethical Perspective of Non-Market Strategy}

If the rational perspective and political perspective are the description and guidance of non-market strategy, then the ethical perspective focuses on the evaluation and reflection of non-market behavior. Ethical perspective assumes that enterprises and society are mutually integrated and indivisible. Enterprise is the engine to promote the progress of modern society and the main creator of social value. The survival of an enterprise depends on the support of the society, and the public has the right to hope or expect the behavior of the enterprise. Therefore, ethical believes the mission of the enterprise is not limited to promote the circulation of commodities or to make profit for shareholders. In fact, the enterprises cannot shirk responsibility for social progress [17] [18]. The code of enterprise is not to minimize the negative impact on society, but to maximize social progress.

Whether the theory of stakeholders is based on the theory of business ethics or not, from the empirical literature, the meaning and connotation of ethical perspective emphasizes the survey of the enterprise from the ethical perspective of non-market behavior, the scope of the study concerning environmental protection, community relations, labor safety and health issues, supplier and customer relationships, stakeholder management and many other issues. Cpeland \& Waddock discussed the problem of enterprise moral deficiency. To solve this problem, Rose conducted an experimental study for senior directors from top 200 enterprises of Fortune Magazine [19]. It is found that the guiding principle of the board of directors is the current company law (the company law emphasizes the maximization of shareholders' interests), rather than the individual moral or social responsibility. In the case of the current company law does not make major adjustments, ethics education cannot cure the moral anomie behavior.

From these empirical studies, it is clearly that "morality", "fairness", "justice" and "social responsibility" are the key words from the ethical perspective. Furthermore, these key words show that the ethical perspective gives a new orientation for the relationship between enterprises and social relations. Ethical perspective is not only limited to the description and induction of the current situation of enterprises, but also advocates standardizing non-market behavior of enterprises on the basis of moral judgment. Compared with the former two perspectives, the ethical perspective emphasizes the spirit of humanism and symbolic meaning in non-market behavior, and less involves in organization's rationality and political nature.

\section{Conclusion and Discussion}

\subsection{Conclusion}

We start from the theoretical background of non-market strategy, try to excavate the theoretical perspective from the current literatures. Focusing on the two issues of "the nature of enterprise" and "the essence of non-market strategy", we find that the existing non-market strategy research is based on the rational, po- 
litical and ethical perspective and different perspectives focus differently on the theoretical basis, basic assumptions and research topics (Table 2). Among them, the rational perspective is a normative research, focusing on the development of non-market strategy and its impact on economic performance; political perspective is a descriptive study, emphasizing the balance of power between the enterprise and its stakeholders; ethical perspective is to judge the behavior of enterprises, focusing on exploring the moral connotation behind non-market strategy. As Bolman and Deal said, the theoretical perspective is a triple prism for scholars to study enterprises' behavior; the different perspective of refraction is a different side of the enterprise reality. From this perspective, the classification method which proposed in this paper is only a relative sense of distinction, rather than the quite distinction from each other.

\subsection{Discussion}

From the purpose and significance of the study, we hope that this paper can provide some contribution and innovation from the following three aspects. Firstly, a non-market strategy is a concept with rich connotation, complicated theoretical background and different forms of non-market means which make it difficult for researchers to get a glimpse of the nature of non-market behavior. Moreover, from the literatures of the past ten years, the rational, political and ethical perspective has made considerable progress in the respective theoretical framework, but there is still a lack of integration and complementarity between

Table 2. Three theoretical perspectives of non-market strategy.

\begin{tabular}{|c|c|c|c|}
\hline $\begin{array}{l}\text { Theoretical } \\
\text { perspective }\end{array}$ & Theoretical basis & Basic assumption & Research topic \\
\hline $\begin{array}{c}\text { Rational } \\
\text { perspective }\end{array}$ & $\begin{array}{l}\text { Transaction cost theory; } \\
\text { institutional theory; resource } \\
\text { dependence theory; } \\
\text { principal-agent theory; } \\
\text { game theory; resource } \\
\text { base model; SWOT model; } \\
\text { five forces model }\end{array}$ & $\begin{array}{l}\text { The enterprise is the } \\
\text { rational organization to } \\
\text { pursue the maximization } \\
\text { of economic benefits, } \\
\text { and the non-market } \\
\text { strategy is the competitive } \\
\text { means for enterprises to } \\
\text { achieve their goals }\end{array}$ & $\begin{array}{l}\text { Focus on the relationship between the enterprise and public } \\
\text { policy; to seek the optimal solution of the non-market areas: } \\
\text { what factors affect the formulation and application of } \\
\text { non-market strategy? What specific enterprise should } \\
\text { adopt non-market strategy to win the best performance? } \\
\text { Enterprise is a rational organization to pursue maximum } \\
\text { economic benefits; non-market strategy is the } \\
\text { competition means for enterprise to achieve its goal }\end{array}$ \\
\hline $\begin{array}{c}\text { Political } \\
\text { perspective }\end{array}$ & $\begin{array}{l}\text { Resource dependence theory; } \\
\text { stakeholder theory; social } \\
\text { network theory; conflict theory; } \\
\text { game theory; bargaining theory; }\end{array}$ & $\begin{array}{l}\text { The enterprise is the } \\
\text { game place of different } \\
\text { interest groups; non } \\
\text { market strategy is the } \\
\text { interaction between } \\
\text { the enterprise and } \\
\text { its stakeholders }\end{array}$ & $\begin{array}{l}\text { To explore the power relationship between the enterprise } \\
\text { and its stakeholders, and to emphasize the balance } \\
\text { between different interest groups: how to manage their stake- } \\
\text { holders and how to influence the decision making? }\end{array}$ \\
\hline $\begin{array}{c}\text { Ethical } \\
\text { perspective }\end{array}$ & $\begin{array}{l}\text { Stakeholder theory; } \\
\text { business ethics theory }\end{array}$ & $\begin{array}{l}\text { Enterprises should take the } \\
\text { responsibility of creating } \\
\text { social value; non-market } \\
\text { strategy should be the } \\
\text { embodiment of enterprise's } \\
\text { social responsibility }\end{array}$ & $\begin{array}{l}\text { Pay attention to corporate social responsibility; } \\
\text { emphasizing the moral connotation from the } \\
\text { perspective of ethics to judge non-market behavior: } \\
\text { Is it the enterprise has the interests of all stakeholders? } \\
\text { Is it to assume full responsibility? Is it } \\
\text { non-market behavior contrary to business ethics? }\end{array}$ \\
\hline
\end{tabular}

Source: according to relevant literature. 
the different perspectives. Therefore, the three perspective classifications not only combine and induct the existing literature but also become the starting point for the integration of different theoretical schools. Besides, from the empirical point of view, the nature of the non-market strategy determines that the theme of the research depends heavily on the cultural background and institutional environment. However, from the existing literature, the majority of empirical conclusions in the field of non-market strategy come from European and American enterprises, so the extent which the existing research results are applicable to Chinese enterprises remains to be defined. For this reason, we focus on the theoretical perspective of the literature, rather than the specific measures of non-market strategy.

In this paper, there are still some problems that have not yet been solved. For example, how to verify the effectiveness of non-market strategy and the problems of the same enterprise development during different stages about non-market behavior changes with time and other issues. These limitations of the paper should be discussed for further research.

Finally, we hope that the theoretical perspective can help Chinese managers understand the ins and outs of non-market behavior from a deeper level and discuss the applicability of European and American enterprises' practical experience to Chinese enterprises. As a result, it can provide practical guidance for non-market activities of Chinese enterprises during the specific period of China's transition.

\section{References}

[1] Freeman, R.E. (1984) Strategic Management: A Stakeholder Approach. Pitman Publishing.

[2] Freeman, R.E. (2004) The Stakeholder Approach Revisited. Zeitschrift für Wirtschafts-und Unternehmensethik, 5, 228-241.

[3] Nafei, Y. (2003) A Symmetrical Inter-Organization Relationships Creation: Achieving Success by Leveraging Resource Dependence and Social Network. PhD Dissertation, Benedictine University, Lisle.

[4] Bonardi, J.-P. (2004) Global and Political Strategies in Deregulated Industries: The Asymmetric Behaviors of Former Monopolies. Strategic Management Journal, 25, 101-120. https://doi.org/10.1002/smj.367

[5] Bonardi, J.-P., Hillman, A.J. and Keim, G.D. (2005) The Attractiveness of Political Markets: Implications for Firm Strategy. Academy of Management Review, 30, 397 413. https://doi.org/10.5465/AMR.2005.16387895

[6] Bonardi, J.-P., Holburn, G.L.F. and Vanden Bergh, R.G. (2006) Non-Market Strategy Performance: Evidence from U.S. Electric Utilities. Academy of Management Journal, 49, 1209-1228. https://doi.org/10.5465/AMJ.2006.23478676

[7] De Figueiredo, J.M. and Tiller, E.H. (2001) The Structure and Conduct of Corporate Lobbying: How Firms Lobby the Federal Communications Commission. Journal of Economics \&Management Strategy, 10, 91-122.

[8] Delios, A. and Henisz, W.J. (2000) Japanese Firms' Investment Strategies in Emerging Economies. Academy of Management Journal, 43, 305-323.

$\underline{\text { https://doi.org/10.2307/1556397 }}$ 
[9] Faccio, M., Masulis, R.W. and McConnell, J.J. (2006) Political Connections and Corporate Bailouts. Journal of Finance, 61, 2597-2635. https://doi.org/10.1111/j.1540-6261.2006.01000.x

[10] Fan, J.P.H., Wong, T.J. and Zhang, T. (2007) Politically Connected CEOs, Corporate Governance, and Post-IPO Performance of China's Newly Partially Privatized Firms. Journal of Financial Economics, 84, 330-357.

[11] Henisz, W.J. and Zelner, B.A. (2004) Explicating Political Hazards and Safeguards: A Transaction Cost Politics Approach. Industrial and Corporate Change, 13, 901915. https://doi.org/10.1093/icc/dth036

[12] Henisz, W.J. and Zelner, B.A. (2005) Legitimacy, Interest Group Pressures, and Change in Emergent Institutions: The Case of Foreign Investors and Host Country Governments. Academy of Management Review, 30, 361-382. https://doi.org/10.5465/AMR.2005.16387892

[13] Servaes, H. and Tamayo, A. (2013) The Impact of Corporate Social Responsibility on Firm Value: The Role of Customer Awareness. Management Science, 59, 10451061. https://doi.org/10.1287/mnsc. 1120.1630

[14] Sharma, S. and Henriques, I. (2005) Stakeholder Influences on Sustainability Practices in the Canadian Forest Products Industry. Strategic Management Journal, 26, 159-180. https://doi.org/10.1002/smj.439

[15] Turban, D.B. and Greening, D.W. (1997) Corporate Social Performance and Organizational Attractiveness to Prospective Employees. Academy of Management Journal, 40, 658-672. https://doi.org/10.2307/257057

[16] Uhlenbruck, K. and Castro, J.O.D. (2000) Foreign Acquisitions in Central and Eastern Europe: Outcomes of Privatization in Transitional Economies. Academy of Management Journal, 43, 381-402. https://doi.org/10.2307/1556401

[17] Yue, L.Q., Luo, J. and Ingram, P. (2013) The Failure of Private Regulation Elite Control and Market Crises in the Manhattan Banking Industry. Administrative Science Quarterly, 58, 37-68. https://doi.org/10.1177/0001839213476502

[18] Mackey, A., Mackey, T.B. and Barney, J.B. (2007) Corporate Social Responsibility and Firm Performance: Investor Preferences and Corporate Strategies. Academy of Management Review, 32, 817-835. https://doi.org/10.5465/AMR.2007.25275676

[19] Zhao, M. (2006) Conducting R \& D in Countries with Weak Intellectual Property Rights Protection. Management Science, 52, 1185-1199.

https://doi.org/10.1287/mnsc. 1060.0516 
Submit or recommend next manuscript to SCIRP and we will provide best service for you:

Accepting pre-submission inquiries through Email, Facebook, LinkedIn, Twitter, etc. A wide selection of journals (inclusive of 9 subjects, more than 200 journals)

Providing 24-hour high-quality service

User-friendly online submission system

Fair and swift peer-review system

Efficient typesetting and proofreading procedure

Display of the result of downloads and visits, as well as the number of cited articles Maximum dissemination of your research work

Submit your manuscript at: http://papersubmission.scirp.org/

Or contact ajibm@scirp.org 